\title{
BEHRINGER, W. Chonrad Stoeckhlin a „noční houf“ (Příběh z raného novověku).
}

\author{
Praha: Argo, 2018, 200 s.
}

\section{Právní historie i „dějiny mentalit“}

Není to poprvé, co v nakladatelství Argo v rámci ediční řady „Každodenní život“ vychází odborná studie, kterou lze po bližším zkoumání zařadit mezi výrazné právně-historické tituly. Nejinak je tomu i v př́padě knihy německého historika Wolfganga Behringera Chonrad Stoeckhlin a ,nočni houf" s prípadným podtitulem Př́běh z raného novověku. A bližšího zkoumání pro zařazení této práce do oblasti právní historie vlastně nakonec ani není třeba, protože už záhy je zjevné, že ústředním tématem zde jsou čarodějnické procesy, přičemž základním pramenem celého príiběhu autorovi byly právě „Procesní akta Chonrada Stoeckhlina“, jež se nacházejí ve Státním archivu v Augsburku.

Autor nás tak hned na úvod uvádí do místa a doby př́iběhu, který se $\mathrm{v}$ celém svém bezpochyby tragickém rozměru odehrál v posledních desetiletích 16 . století v Obertsdorfu, jenž „náležel k rettenburskému soudnímu okruhu, nejjižnějšímu z 16 správních okruhů augsburského biskupství“ (s. 9). Stejně tak se nám v úvodu dostává i základních informací o hlavním protagonistovi všeho dění, jímž je už v titulu knihy uvedený Chonrad Stoeckhlin, svou profesí pasák koní, jehož život je neodmyslitelně spjat s vysokohorskými údolími Alp.

Z pohledu čtenáře je přitom důležité, že autor při současném splnění všech požadavků na kvalitní vědeckou publikaci dokáže zároveň vystavět, a především vyprávět poutavý př́běh, jehož základní obrysy nastiňuje právě v prvých kapitolách knihy. Dozvídáme se tak, že Stoeckhlin vykročil na cestu, na jejímž konci bude pro něj coby „usvědčeného čarodějníka" stát hranice, na níž bude upálen roku 1578, kdy uzavřel dohodu se svým př́itelem pasákem volů Walchem o tom, že ten z nich, kdo zemře dř́ve, zpraví toho druhého o poměrech „na onom světě““.

A je to právě Walch, který záhy na to umírá a věren slibu „informuje“ Stoeckhlina (a to vlastně poměrně „,ř̌est’ansky pravověrně“) o tom, ,jaké to je po smrti“. Tím ovšem zázračné události nekončí, právě naopak - tím se jejich řetězec teprve počíná. Pasákovi koní se totiž zjevuje anděl, v jehož doprovodu putuje ve stavu bezvědomí a bez vlastního přičinění do dalekých míst, o nichž se domnívá, že to byly očistec a ráj. Následně pak komunikace $\mathrm{s}$,jiným světem“ získává na pravidelnosti a Stoeckhlin se přímo stává občasnou součástí putujícího ,nočního houfu“.

Zde Behringer své vyprávění př́iběhu na poměrně dlouhou dobu přerušuje, aby jej ale o to pevněji ukotvil v dobovém kontextu a terminologii. Možná by tak šlo i říci, že se nám v řadě následujících kapitol dostává velmi fundovaného a zasvěceného pohledu do dobové 
mentality, z níž jeho vyprávění vyrůstá, a jedině v jejímž rámci lze celé tehdejší dění také pochopit. Nejprve jsme tak obeznámeni právě s termíny „noční houf“ a „noční lid“, které při vší své nepochybné podobnosti nejsou úplně zaměnitelné. K tomu se pak ostatně váží i kapitoly o „nadpozemsky krásné hudbě“ a „zázracích s kostmi“, které nezrrídka „letecké putování nocí" doprovázejí. Cenné prritom je, že autor při tomto výkladu nezůstává omezen jen na ,alpská údolí“, ale uvádí i srovnatelné příklady z jiných oblastí.V následující rozsáhlé deváté kapitole si pak ovšem již všímá i kontextu právního vývoje, kdy především vyzvedává význam textu „Canon episcopi““, jenž v té době představoval již řadu století doslova kanonický pramen k ,interpretaci nočních letů“ (s. 54). Jeho původ přitom Behringer konkrétně odvozuje již z karolinského kapituláře, jenž byl později zahrnut i do „Gratianova dekretu“ sestaveného roku 1142, a nabyl tak ,postavení závazného textu v souboru církevně právních nařizení“ (s. 55). Dále nás provádí právě i historií náhledů a posuzování zázračných událostí, přičemž zdůrazňuje, že byt' se zázraky mohly i „tvářit pravověrně“, pro ty, kdo na nich byli účastni, spočívalo velké nebezpečí už v tom, že touto samotnou skutečností narušovali monopol církví na jejich důslednou kontrolu a správu. V této souvislosti tak cituje i řadu dobových autorit a démonologů, kteří se problematice věnovali, přičemž neopomíná vyzvednout ani negativní dopad nauky slavného Jeana Bodina, o němž je právě již méně známo, že byl i autorem díla „De magorum daemonomania“, jež bylo poměrně záhy po svém vzniku přeloženo i do němčiny.

Po tomto opravdu důkladném a neošizeném přiblížení kontextu případu se tak autor vrací opět ke svému příběhu pasáka koní Stoeckhlina, který se v letech, kdy byl účasten na zázračném nočním putování, v očích svého okolí etabloval i jako „čarodějnický doktor“, tedy ten, jehož působení je schopno čelit úkladům čarodějnic. Jenže právě už pouhá blízkost „čarodějnické problematice“ se mu stává zásadně přitěžující ve chvíli, kdy v létě roku 1586 řada bouří poničila $\mathrm{v}$ augsburském biskupství úrodu, a navíc se zde rozšíríila i smrtící epidemie neznámé nemoci.

Nyní se tedy stává Stoeckhlinovi osudným, že jako místní oberstdorfský odborník na zázračné jevy vysloví podezření ohledně čarodějnictví jedné místní staré ženy, která se v panice následně pokusí uprchnout, což je v podstatě vnímáno jako přiznání viny. Žena je nakonec „uvězněna oberstdorfskými soudci a přísežnými, kteří důvěřovali v pastýřovu věrohodnost“" (s. 92). Tím je ovšem v kontextu výše uvedených neblahých událostí probuzen i zájem soudních úředníků augsburského biskupa, kteří nechají Stoeckhlina zatknout a podrobit výslechům.

Ty pak nebyly rozhodně brány na lehkou váhu (dochovaný soupis vykazuje až 146 otázek), přičemž pro Stoeckhlina byla základním problémem premisa, podle níž „,nikdo nemůže rozpoznat čarodějnice, pokud sám nepatří do jejich společnosti““ (s. 96). Nám již známý př́iběh je tak reinterpretován (z anděla se kupř́ikladu stává „d'ábelská milenka“), kdy Stoeckhlinovi navíc přitíží i svědectví jím samým obviněné ženy, která vypoví, že se čarodějnictví vyučila u jeho zemřelé matky, přičemž právě příbuzenství s čarodějnicemi je v dobovém kontextu považováno za nejzávažnější znak čarodějnictví.

Na následujících stranách knihy se tak dostáváme k samotnému jádru jejího sdělení, jímž je nepochybně právě dobové a místní pronásledování čarodějnic. Autor zde se zřejmou erudicí vytěžil prameny $\mathrm{k}$ prrípadu se vztahující, aby nám představil ve svých důsledcích otřesný příběh násilí a utrpení, nebot' se vším důrazem použitá tortura roztočila nikoliv neobvyklý řetěz udání, jež vtahovaly do vyšetřování stále nové a nové, a nyní již 
vlastně výhradně ženské, oběti. Samotný Stoeckhlin je po krutém vyšetřování upálen již v lednu 1587, přičemž v oblasti působnosti oberstdorfského soudu šlo nakonec dohromady podle Behringerových zjištění o popravu 68 osob (celkově se jednalo při tomto největším pronásledování čarodějnic mezi Dunajem a Alpami v průběhu pěti let o více než 150 osob, přičemž přes 95 procent $\mathrm{z}$ nich představovaly ženy, kdy nejsou navíc započítány i mnohé oběti, jež na následky mučení zemřely již ve vyšetřovací vazbě).

V závěrečné části své knihy se autor konečně opět vrací k fenoménu „lidové víry“ v nadpřirozeno, šamanismu a „soukromým zjevením“, aby zcela na závěr - v kapitole príznačně nazvané „Konec doby snů“ - konstatoval, že Stoeckhlin byl podle něj tím, kdo svým životem a působením nevědomky usiloval „o kompromisní řešení mezi mýtem, tridentským katolicismem a lidovými potřebami, avšak nemohl ho nalézt", a představoval takto vlastně i jakéhosi ,virtuose lidové kultury“ (s. 160).

Na závěr lze konstatovat, že čarodějnické procesy jsou dodnes jistě pro mnohé autory i čtenáře ,atraktivním tématem“, jen málokdy se jim však dostane tak podnětného zasazení do kontextu dobového vnímání. Behringer tak dle mého soudu napsal skutečně výbornou studii, jež se při zhodnocení původních pramenů i sekundární literatury pohybuje zajímavě na hraně právní historie a „dějin mentalit“, a především čtenáře inspiruje k hlubšímu promýšlení této problematiky.

doi: $10.14712 / 2464689 X .2020 .40$

Radim Seltenreich 